\title{
Speculate, speculation, speculative: What can the Energy Humanities do?
}

\section{Bradon Smith}

As Castell, Willis and Waddington noted at the inaugural ScienceHumanities international colloquium, a number of specialist sub-fields have been negotiating the interaction with the sciences within the humanities for some time, and it is important to learn from, rather than replace, these practices. The now established field of the Environmental Humanities, "a transdisciplinary matrix" in the words of Ursula Heise (Comparative Literature n.p.), is one such practice: as Stephen Muecke puts it in an essay for Latour's Reset Modernity!, "what about the 'environmental humanities' maybe this new subfield has some solutions for reconciling the sciences with the humanities, real-world experimentation with the 'life of the mind'?" (Recomposing the Humanities 227). In this essay, I will consider what the Environmental Humanities, and particularly its newer relation the Energy Humanities, can teach us about the kinds of transdisciplinary matrices advocated by the ScienceHumanities.

\section{The study of energy}

Two features of energy set it apart as an object of study for the ScienceHumanities. The first is its topicality - not to say urgency - via its intimate connection, in society's current relationship with it, to climate change. In a 2013 review of theoretical and empirical literature on the politics of energy, Hughes and Lipscy observe that "the politics of energy is reemerging as a major area of inquiry for political science after two decades of relative quiet" (450). They attribute this partly to a very high crude oil price, a factor relevant in 2013 but which no longer explains a continuing interest in energy politics (crude oil prices are in late 2017 exactly half what they were in summer 2013). They also identify "the growing focus of governments on climate change" (450); a focus which has only been sharpened over the past five years. Indeed, the politics of climate change has become increasingly dominated by the politics of energy.

The second feature of energy and its related systems is the near-total penetration into society and culture on all levels: technological, infrastructural, social, economic, geo-political, ethical, temporal, imaginative, and aesthetic. As energy's modern sine qua non, few substances can claim the physical, social and cultural omnipresence of petroleum. To say that plastics are ubiquitous is an understatement: they are present in every one of the oceans, including in organisms in the Mariana trench (Taylor n.p.) and have been found to be the basis of "rafts of biodiverse ecologies for bacteria and viruses" dubbed the Plastisphere (Davies 235). Tests have detected traces of oil and the dispersant Corexit in the blood of Gulf residents in the wake of the Deepwater Horizon oil spill (Atkinson 217). Hydrocarbons continue to dominate energy supply, with oil still "the world's leading fuel, accounting for a third of global energy consumption" in 2016 (BP 2), and global economies remain underpinned by oil prices. Finally, there is a burgeoning body of cultural and artistic practice around energy and climate change. While artists have been responding to the idea of anthropogenic climate change for three decades at least, the last ten years have seen an increase in attention: take, for example, the emergence of cli-fi and petrofiction (two distinct and growing genres of novels) and a steady stream of 
climate change plays (see artistsandclimatechange.com for a growing database), and the undergraduate courses on climate change fiction.

This second feature of energy urges not only the study of energy in general, but also immediately reveals the need for the study of energy by complexes of cross-, multi-, inter- or trans-disciplines. Cross Multi Inter Trans was the title of the 2017 Association for the Study of Literature and Environment (UK and Ireland) conference, and the prefixes hint at the fact that we have not settled on which of these distinctions we find useful. These complexes clearly include, but are not limited to, the humanities. The ScienceHumanities proposes that one means of exploring the interactions of science and culture is through the study of objects which do not already have disciplinary affiliations. Certainly the tangle of interrelated problems around energy generation and demand, personal carbon emissions and climate change, and the intimate connection between capital and the fossil fuel industry, make our contemporary energy challenge no respecter of disciplinary boundaries. Climate change also challenges temporal and spatial scales: personal energy actions have global and inter-generational consequences.

Despite this, the study of energy in the humanities has only recently gained momentum. Hughes' and Lipscy's remark in 2013 is revealing: "the study of energy is also interdisciplinary, incorporating work in the natural and social sciences, and includes different levels of governance from the subnational to the national, regional, and global" (450). But why only the natural and social sciences? Energy and our relationship with it is as much cultural as it is social, and the politics of it as much personal as national or transnational. Energy cannot and should not, then, be understood in disciplinary isolation: it is becoming increasingly clear that to consider, say, the ethical consequences of current petroleum exploration, without in turn understanding the economics that compel such activity, the telescoping temporalities of climate change and intergenerational justice, and the extraordinary grip on our cultural imaginaries of a petroleum-based lifestyle, will reveal only a narrow slice of the question, and a limited answer.

\section{The Energy Humanities}

The environmental challenges associated with the consequences of our current energy system are described by, but then immediately spill out of, the environmental sciences. To take one example: climate modellers build General Circulation Models that attempt to account for the multitude of climate-forcing variables and feedback loops that might accelerate temperature change. But one of the most significant unknowns in this modelling is future changes in global carbon emissions. Models are generally run against the IPCC Special Report on Emissions Scenarios (IPCC), a set of differing scenarios positing a range of futures which make assumptions about human activity: in other words, how quickly carbon emissions might rise or fall as a result of societal changes. Immediately, these are scenarios based not on physical but on political, social, economic and cultural variables.

Scenarios such as the IPCC's provide an apparently solid ground from which to model the future. Scenarios are now a widespread tool in the oil industry too, with the Shell Scenarios the most well-known example. But the ubiquity of scenario planning in business may obscure the fact that scenarios are, in essence, fictions: more or less plausible stories of the future to be used as a starting point for imagining responses to the unknowable. As Renata Tyszczuk reminds us, the term scenario has its roots in the scenari of the commedia dell'arte - a rough outline of the story to be fleshed out all improvviso by the actors (106). The term can be traced via Hollywood 
screenwriters to the strategic planning techniques of the Rand Corporation, and from there into the horizon-scanning and foresight industries.

The ethnographer and exponent of fictocriticism Stephen Muecke writes that "the humanities do need a pat on the back, a reassurance that they, too, deal in real worlds, and not just in representations thereof" (An Ecology of Institutions 232). But in the case of the speculative fictions of scenarios as used in policy and industry, the representational and the real blur; these are productive fictions, representations of future worlds that inform decisions about the real world in the present. These scenarios are different in context, but are nonetheless related to the speculative fictions of our energy futures in the narrative arts - in novels, films, plays, and television shows - which have received attention in the Energy Humanities in recent years. So, what can these works of speculative fiction teach us? Two related issues emerge.

Firstly: the commonplace view that our visions of the future reveal our current fears and desires holds true for energy fiction, or as the Petrocultures Research Group put it, "Energy futures tell us more about the present than they do about the future" (Petrocultures Research Group 63). Scholars such as Imre Szeman have noted a concern that most stories of imagined energy futures fall into one of two categories: a techno-utopianism that encourages a false hope in technological solutions, or a genre of eco-apocalypse which may act as cautionary tales, but offer little to suggest how we might avoid it (System failure 808). The problem with the first of these, Szeman writes elsewhere, is that it continues a narrative of energy surplus, a narrative in which "the promise of the future underwrites and legitimizes the bad faith of the present" (Literature and energy futures 325). In their book Oil Culture, Barrett and Worden agree that "many 'green' visions of the world entail maintaining our lives and practices as they exist with petroleum and simply swapping oil out for a different energy source that magically takes its place and replicates precisely its roles. . . this failure of imagination can be partially remedied by understanding how oil works in culture" (xix).

Secondly, and related to the first: our petroculture is highly resistant to change, even imaginative change. Even with the imaginative freedom that might be denied to writers of the Shell Scenarios, narrative fictions - even those, like many sf fictions, which explicitly engage with energy futures - find it remarkably difficult to imagine the world beyond petroleum. Szeman observes, "Oil capital seems to represent a stage that neither capital nor its opponents can think beyond", and the same appears true of speculative fiction (System Failure 808). Barrett and Worden agree that "we are largely incapable of imagining a world without oil" (xxi).

I call this the persistence of petroleum. Examples can be found in many narratives of future energy, even those apparently depicting a post-carbon future. In Cormac McCarthy's The Road, for example, the father and son cleave to the highway - the ley lines of petrotopian America - which they navigate by a "tattered oilcompany map" (MacDonald 13). In this post fossil-fuel world, they remain in thrall to the landscape built by our Anthropocenic petro-society. John Hillcoat's film adaption gives centre stage to the extraordinary landscapes of our apparently ruined future, but as Alexa Weik von Mossner has observed, these were filmed in real contemporary landscapes of "the decaying ruins and remnants of [Pittsburgh's] coal and steel industry" (45): an example of what Ursula Heise calls the "already if incompletely materialized future that makes palpable the obsolescence of the present" (Invention of Eco-futures 5). 


\section{Speculations}

While we can learn from these works of speculative fiction about our current dependency on petroleum, considering these in parallel with the scenarios from industry and politics helps to reveal a bigger picture - the essential role of narrative in the energy system. Instead of trying to see how stories might help us to understand our present economic and political energy realities, and the possible future alternatives to the matrix of social, political and economic structures that underpin our present energy system, we can understand rather that the study of these realities is also partly a study of these narratives. The economic and political systems that underpin the drilling for oil, capital investment in petroleum giants, and even international climate legislation, are built on narrative foundations.

Discovering oil is predicated on speculation, on scenarios of future discovery. Oil exploration now uses a range of techniques to search for new reserves, but the process is still an expensive and risky one; early oil drilling, or wildcatting, was even more speculative. Martin McQuillan sees a "clear and legible connection between what the oil industry calls 'speculation' and the speculative philosophical enterprise" (277). He goes on to suggest that:

speculating for oil has been the basis of industrial modernity and the western economy for the last two hundred years [...]. As that which fuels the engine of the economy, that which makes the economy as such possible, the search for oil is an investment in a venture with the hope of gain but with the risk of loss. The speculative structure of oil exploitation follows from and is now itself the basis for the structure of all investment in stock, property, and the fictional products of capital today. (277)

As McQuillan realises, there is a connection between the speculative basis of oil prospecting, and all capital speculations that form the basis of the global economy not coincidentally shored up on the price of oil. The line of connection that can be drawn between speculating for oil and the speculative structure of all capital investment runs through the speculation of fiction. It is narrative that has allowed these speculative systems to flourish. What this common term speculation reveals is that the drilling of an oil well, the investment in a stock, and the crafting of a sci-fi narrative share the element of fiction.

The importance of imagination and narrative to the process of oil exploration has been demonstrated by Paul Warde in his account of arctic oil prospecting. The story of oil discovery needs to be told before the investment and commitment to finding it can be made: "discovery was underpinned by imagination and will as well as geological knowledge. Narrative and technical choice are thus, in fact, close bedfellows" (Warde, n.p.). Warde quotes the then vice-president of Standard Oil of New Jersey, Wallace E. Pratt, who declared that "unless men can believe that there is more oil to be discovered, they will not drill for oil [...] Where oil is first found, in the final analysis, is in the minds of men" (quoted in Warde).

That capitalism too is a system built on the power of fictions has been argued recently by scholars in economic sociology. This is not just a question of speculation in the sense of risk and possible reward as used by McQuillan, but is entirely to do with the writing of convincing fictions of the future. As Jens Beckert has argued, fictions are fundamental: "the decision-making of intentionally rational actors [in economic contexts] is anchored in fictions [...] The mental representations of future states I call 'fictional expectations'. Fictional expectations in the economy take 
narrative form as stories, theories, and discourses" (Beckert 219-220). These fictions, he continues, "do not have to be true but must be convincing", which can be said of any piece of narrative art. Arguing for the radical quality of the imagination in its capacity to "produce ideas and visions of the future that materially condition the present", Komporozos-Athanasiou and Bottici likewise concede that "the imagination driving our dystopian present is nowhere more prominent than in the fictitious operation of financial capitalism" (n.p.).

\section{Conclusion}

One thing this account of the narratives at the heart of our energy systems reveals is that the Energy Humanities is something of a misnomer, since the focus on energy requires a transdisciplinary attention that quickly breaks out of the humanities, encompassing the social and natural sciences too: the Energy ScienceHumanities might better serve. Regardless, it suggests the importance of increasing attention to energy that spans disciplinary boundaries. As Ursula Heise writes, "the current recognition that environmental crisis and, more broadly, humans' uses of nature have to be a primary concern for humanistic research opens up wider possibilities for redefining environmental scholarship beyond, in between, or outside of disciplinary conventions" (Comparative Literature and the Environmental Humanities n.p.).

The Environmental and Energy Humanities give strong support to the practices advocated by the ScienceHumanities, by showing the value of an approach embedded in long-standing humanities methods - the study of narrative, say - to objects and processes that have traditionally existed outside these disciplines. The connection drawn here between oil speculation, capital speculation, and speculative literary fictions, is not intended to somehow trivialise the mechanisms employed by capital and industry as mere story. Indeed, that very idea reveals something of the epistemological hierarchies that perhaps necessitate interventions such as the ScienceHumanities. On the contrary, it confirms the power of imagined futures in these contexts: a core humanities concept - narrative - sits at the centre of connections between capital and energy, and is central also to our construction of our energy future. 


\section{Works Cited}

Atkinson, Ted. “'Blood Petroleum': True Blood, the BP Oil Spill, and Fictions of Energy/Culture." Journal of American Studies, vol. 47, no. 01, Feb. 2013, pp. 213-229. Cambridge Journals Online, doi:10.1017/S0021875812001247.

Barrett, Ross, and Daniel Worden. Oil Culture. U of Minnesota P, 2014.

Beckert, Jens. "Imagined Futures: Fictional Expectations in the Economy." Theory and Society, vol. 42, no. 3, May 2013, pp. 219-40. CrossRef, doi:10.1007/s11186-013-9191-2.

BP Statistical Review of World Energy June 2017. 2017, www.bp.com/content/dam/ bp/en/corporate/pdf/energy-economics/statistical-review-2017/bp-statisticalreview-of-world-energy-2017-full-report.pdf. Accessed 11 Dec. 2017.

Davis, Heather. "Toxic Progeny: The Plastisphere and Other Queer Futures." PhiloSOPHIA, vol. 5, no. 2, Feb. 2016, pp. 231-50.

Heise, Ursula K. "Introduction: The Invention of Eco-Futures.” Ecozon@: European Journal of Literature, Culture and Environment, vol. 3, no. 2, Jan. 2012, pp. $1-10$.

---. "Comparative Literature and the Environmental Humanities." State of the Discipline, Mar. 2014, stateofthediscipline.acla.org/entry/comparativeliterature-and-environmental-humanities. Accessed 11 Dec. 2017.

Hughes, Llewelyn, and Phillip Y. Lipscy. "The Politics of Energy." Annual Review of Political Science, vol. 16, no. 1, May 2013, pp. 449-69. doi:10.1146/annurevpolisci-072211-143240.

Intergovernmental Panel on Climate Change (IPCC), and Working Group III. Emissions Scenarios. a Special Report of IPCC Working Group III. Intergovernmental Panel on Climate Change, 2000.

Komporozos-Athanasiou, Aris, and Chiara Bottici. "The Radical Imagination: Imagining the Future in Financial Capitalism." Public Seminar, 2 June 2017, www.publicseminar.org/2017/06/the-radical-imagination. Accessed 11 Dec. 2017.

Petrocultures Research Group. After Oil. West Virginia UP, 2016.

MacDonald, Graeme. "Research Note: The Resources of Fiction." Reviews in Cultural Theory, vol. 4, no. 2, 2013, pp. 1-24.

McQuillan, Martin. "Notes Toward a Post-Carbon Philosophy." Telemorphosis: Theory in the Era of Climate Change, Vol. 1, edited by Tom Cohen, Open Humanities Press, 2012, pp. 270-92.

Muecke, Stephen. "Recomposing the Humanities." Reset Modernity!, edited by Bruno Latour, MIT Press, 2016, pp. 224-29.

---. "An Ecology of Institutions: Recomposing the Humanities." New Literary History, vol. 47, no. 2-3, 2016, pp. 231-48. doi:10.1353/nlh.2016.0012.

Smith, Joe, et al., editors. Energetic: Exploring the Past, Present and Future of Energy. Shed, forthcoming, 2018.

Szeman, I. "System Failure: Oil, Futurity, and the Anticipation of Disaster." South Atlantic Quarterly, vol. 106, no. 4, Oct. 2007, pp. 805-23. doi:10.1215/00382876-2007-047.

---. "Literature and energy futures." "Editor's Column: Literature in the Ages of Wood, Tallow, Coal, Whale Oil, Gasoline, Atomic Power, and Other Energy Sources," by Patricia Yaeger et al., PMLA, vol. 126, no. 2, 2011, pp. 305-326. doi:10.1632/pmla.2011.126.2.305. 
Taylor, Matthew. "Plastics Found in Stomachs of Deepest Sea Creatures." The Guardian, 15 Nov. 2017, www.theguardian.com/environment/2017/nov/15/ plastics-found-in-stomachs-of-deepest-sea-creatures. Accessed 11 Dec. 2017.

Warde, Paul. "Constructing Arctic Energy Resources: The Case of the Canadian North, 1921-1980." Competing Arctic Futures: Historical and Contemporary Perspectives, edited by Wormbs, N. Palgrave, forthcoming, 2018.

Weik von Mossner, Alexa. "Afraid of the Dark and the Light: Visceralizing Ecocide in The Road and Hell." Ecozon@: European Journal of Literature, Culture and Environment, vol. 3, no. 2, Oct. 2012, pp. 42-56. 